\title{
Leksikon kegulmaan pada masyarakat Jawa di Perkebunan Fajar Agung, Kecamatan Pegajahan, Kabupaten Serdang Bedagai: Kajian ekolinguistik
}

\author{
Wiradi Putra ${ }^{\mathrm{I}^{*}}$, Dwi Widayati ${ }^{\mathrm{a} 2}$, Dardanila ${ }^{\mathrm{a} 3}$, dan Sharina Amanda ${ }^{\mathrm{b} 4}$ \\ ${ }^{a}$ Fakultas Ilmu Budaya, Universitas Sumatera Utara, Jalan Universitas No.19, Padang Bulan, Kota Medan, Sumatera Utara, Indonesia \\ ${ }^{b}$ Program Studi Manajemen Akuntansi, Politeknik Unggul LP3M Medan, Jalan Iskandar Muda No. 3 CDEF, Kota Medan, Sumatera Utara, \\ Indonesia \\ Iwiradiputra917@gmail.com,dwiwidayati0831@gmail.com²,dardanila@usu.ac.id²,sharinaamanda@gmail.com \\ *Corresponding author: wiradiputra917@gmail.com
}

\begin{tabular}{l} 
Sejarah Artikel Diterima: I9 Februari 202I $\begin{array}{c}\text { Direvisi: 24 April 202I } \\
\text { ABSTRAK }\end{array}$ \\
\hline Masyarakat Jawa Fajar Agung merupakan pekerja perkebunan yang sangat akrab dengan leksikon-leksikon kegulmaan. \\
Keakraban ini dapat terlihat dari penggunaan leksikon yang masih bertahan sampai saat ini. Hal ini merupakan salah satu \\
cara dalam pencegahan punahnya istilah Jawa dalam bentuk leksikon kegulmaan. Penelitian ini bertujuan untuk \\
mendeskripsikan tingkat pemahaman masyarakat Jawa terhadap leksikon kegulman di Perkebunan Fajar Agung, serta \\
menjelaskan faktor yang memengaruhi tingkat pemahaman masyarakat Jawa terhadap leksikon kegulmaan di Perkebunan \\
Fajar Agung. Penelitian ini menggunakan pendekatan kualitatif yang didukung berupa perhitungan hasil respondensi secara \\
kuantitatif. Data leksikon kegulmaan diperoleh melalui angket. Angket berisi data daftar leksikon kegulmaan yang \\
sebelumnya diperoleh melalui wawancara kepada informan kunci. Adapun hasil penelitian ini, yaitu Leksikon kegulmaan \\
pada masyarakat Jawa di Perkebunan Fajar Agung berjumlah 75 buah. Berdasarkan pada pembahasan pertama tingkat \\
pemahaman T (tahu) kelompok usia I (25-45 Tahun) yaitu 83,53\% dan kelompok usia II (46-60 Tahun) yaitu 83,I5\% \\
sehingga dapat disimpulkan bahwa masyarakat Jawa di Perkebunan Fajar Agung masih mengenal dan menggunakan leksikon- \\
leksikon kegulmaan dalam bahasa Jawa. Berdasarkan pembahasan kedua, terdapat dua faktor kebertahanan yang \\
memengaruhi tingkat pemahaman leksikon kegulmaan pada MJFA, yaitu yaitu faktor yang berkaitan dengan linguistik dan \\
non-linguistik. Faktor linguistik yang memengaruhi kebertahanan leksikon kegulmaan pada MJFA, yaitu berhubungan \\
dengan tendensi MJFA terhadap bahasa Jawa. Kemudian faktor non-linguistik, yaitu perilaku konservatif MJFA terhadap \\
gulma, adaptasi fisiologi gulma terhadap herbisida, konsistensi penggunaan peralatan tradisional pengendalian dan \\
pemberantasan gulma, kesejahteraan MJFA, pendidikan MJFA.
\end{tabular}

\section{Kata Kunci Ekolinguistik, Gulma, Kebertahanan bahasa, Kegulmaan, Leksikon}

ABSTRACT

The Javanese Fajar Agung people are plantation workers who are very familiar with the lexicons of pleasure. This familiarity can be seen from the use of the lexicon which has survived to this day. This is one way to prevent the extinction of the Javanese term in the form of the lexicon of pleasure. This study aims to describe the level of Javanese understanding of the lexicon of weedness in Fajar Agung Plantation, as well as to explain the factors that influence the level of Javanese understanding of the lexicon of weedness in Fajar Agung Plantation. This study uses a qualitative approach which is supported in the form of quantitative calculation of the respondent's results. The lexicon data obtained through a questionnaire. The questionnaire contains data on a list of pleasure lexicons previously obtained through interviews with key informants. The results of this study, namely the lexicon of pleasure in Javanese people in Fajar Agung Plantation, amounted to 75 pieces. Based on the first discussion, the level of understanding T (Tahu) for age group I (25-45 years) is $83.53 \%$ and age group II (46-60 years) is $83.15 \%$, so it can be concluded that the Javanese people in Fajar Agung Plantation are still recognize and use pleasure lexicons in Javanese. Based on the second discussion, there are two factors of survival that affect the level of understanding of the lexicon of pleasure in MJFA, namely factors related to linguistics and nonlinguistics. Linguistic factors that influence the survival of the literary lexicon in MJFA are related to the tendency of MJFA towards Javanese. Then the nonlinguistic factors, namely MJFA's conservative behavior towards weeds, physiological adaptation of weeds to herbicides, consistency in the use of traditional weed control and eradication tools, MJFA welfare, MJFA education.

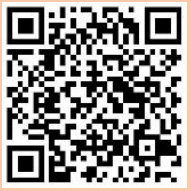

Copyright@202I, Wiradi Putra, Dwi Widayati, Dardanila dan Sharina Amanda

This is an open access article under the CC-BY-3.0 license

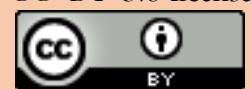

Keywords $\quad$ Ecolinguistics, Weeds, Persistence of language, Weeedness, Lexicon

How to Cite Putra, W., Widayati, D., Dardanila, \& Amanda, S. (202I). Leksikon kegulmaan pada masyarakat Jawa di Perkebunan Fajar Agung, Kecamatan Pegajahan, Kabupaten Serdang Bedagai: Kajian ekolinguistik. 
KEMBARA: Jurnal Keilmuan, Bahasa, Sastra dan Pengajarannya (e-Journal), 7(I), I82-199. doi: https://doi.org/I0.22219/kembara.v7iI.I5432

\section{PENDAHULUAN}

Masyarakat Jawa yang ada di Perkebunan Fajar Agung (selanjutnya disebut MJFA) sudah menetap puluhan tahun sejak suku Jawa didatangkan oleh pemerintah kolonial Belanda sebagai kuli kontrak ke Sumatera Timur (saat ini Sumatera Utara). Didatangkannya kuli kontrak dari Pulau Jawa sesuai dengan politik etis pemerintah Belanda saat itu. Diemigrasikannya para kuli kontrak ini disebabkan oleh adanya ledakan jumlah penduduk di Pulau Jawa saat itu (Herdiansyah, 2017). Selain adanya ledakan jumlah penduduk di Pulau Jawa, emigrasi ini dilakukan karena adanya pembukaan lahan perkebunan secara besar-besaran di Sumatera Timur, sehingga membutuhkan tenaga kerja yang cukup besar (Herdiansyah, 2017).

Pembukaan lahan secara besar-besaran ini tentunya memengaruhi lingkungan alam yang ada di sekitar area perkebunan serta hilangnya fungsi kawasan seperti yang dikatakan oleh (Hidayah dan Dharmawan, 2016) bahwa munculnya permasalahan berupa hilangnya fungsi kawasan sebagai pelindung keanekaragaman hayati dan perlindungan terhadap satwa di Pulau Sumatera. Selain praktik pembukaan lahan perkebunan ini, perusakan lingkungan juga dilakukan karena adanya usaha-usaha pengendalian dan juga pemberantasan hama dan gulma di sekitar area perkebunan. Contohnya saja penggunaan pestisida yang tidak terukur oleh manajemen perusahaan. Ketidakterukuran ini dapat disebabkan oleh faktor pengetahuan, maupun faktor ekonomis yang mengharuskan penggunaan pestisida yang kurang tepat. Hal ini sejalan dengan yang dikatakan oleh (Arif, 20I5) bahwa pengendalian hama dan gulma secara biologi dan ekologi dirasa kurang efektif dengan menggunakan pestisida buatan atau sintetis yang memakan biaya sedikit dibandingkan cara-cara lama.

Bentuk kepedulian terhadap lingkungan ini pernah disinggung oleh (Adriyani, 2006) yang menjelaskan bagaimana dampak negatif lingkungan yang diakibatkan oleh penggunaan pestisida yang berlebihan. Dampak negatif yang timbul akibat penggunaan pestisida tersebut meliputi: (a) pencemaran air tanah, (b) pencemaran udara, (c) timbulnya spesies hama yang resisten, (d) timbulnya hama baru atau ledakan hama sekunder, (e) merusak keseimbangan ekosistem, (f) dampak terhadap kesehatan masyarakat. Selain itu, usaha untuk meminimalkan biaya pemberantasan hama dan gulma ini berdampak pada lingkungan, misalnya saja pencemaran udara. Hal tersebut disinggung oleh (Arif, 2015) bahwa masuknya pestisida di udara disebabkan oleh driff yaitu proses penyebaran pestisida ke udara melalui penyemprotan oleh petani yang terbawa angin. Akumulasi pestisida yang terlalu berat di udara pada akhirnya akan menambah parah pencemaran udara.

Usaha-usaha penyelamatan lingkungan dalam makalah-makalah dampak pestisida terhadap lingkungan ini juga sudah disampaikan secara baik, seperti pengelolaan pestisida yang baik, penggunaan pestisida secara aman, pengawasan terhadap penggunaan pestisida, dan penggunaan sistem pertanian yang kembali ke alam. Ini semua merupakan upaya-upaya untuk mengurangi dampak negatif yang berasal dari penggunaan pestisida. Namun, semua itu hanya memikirkan dampak ekonomis maupun hanya memikirkan keuntungan serta keselamatan manusia saja, tetapi tidak pernah terpikirkan bagaimana dampaknya terhadap keberadaan tanaman-tanaman yang sering dianggap mengganggu tersebut. Petani sering menyebutnya gulma. Gulma adalah tumbuhan yang tumbuh tidak diinginkan kehadirannya baik secara tempat maupun waktu. Gulma mempunyai sifat berasosiasi dan dapat mendominasi lahan budidaya. Gulma tumbuh pada tempat yang kaya unsur hara sampai yang kurang unsur hara. Gulma pada umumnya mudah dalam melakukan regenerasi, sehingga unggul dalam persaingan memperoleh ruang tumbuh, cahaya, air, unsur hara, dan $\mathrm{CO}_{2}$ dengan tanaman budidaya (Iyung, 2008).

Karena sifatnya yang mengganggu dan kekuatannya inilah, petani berusaha untuk memberantasnya. Padahal, tidak semua gulma-gulma tersebut mengancam tanaman perkebunan, ada juga gulma yang dapat dimanfaatkan, seperti gulma echinacea yang dapat dimanfaatkan sebagai bahan penangkal radikal bebas dan juga mampu menangkal virus Covid-19. Hal ini seperti yang dikatakan oleh 
(Adjeng, et al, 2020) beberapa tanaman dapat digunakan sebagai imunomodulator atau peningkat sistem imun seperti kunyit, jahe, temulawak, meniran, jambu biji, sambiloto, echinacea, atau dan memiliki efikasi lainnya seperti antiinflamasi dan antioksidan.

Beberapa gulma di atas merupakan petanda bahwa hubungan simbiosis mutualisme antara manusia dengan lingkungan hidup, kajian ekolinguistik mencoba mendeskripsikan tanda yang dimiliki oleh para penutur di daerah tertentu. Masyarakat petani perkebunan contohnya, mereka tentunya sangat akrab dengan budaya pertanian yang berhubungan dengan istilah-istilah perkebunan yang terpantulkan melalui dunia hayati yang dibudayakan oleh mereka di daerahnya. Keakraban ini tentunya ada luntur apabila lingkungan yang menjadi ekosistem antara penutur dengan objek hayatinya tidak terjaga dengan baik.

Kemudian tugas para peneliti adalah menjaga lingkungan. Menjaga lingkungan berarti menyelamatkan. Menyelamatkan lingkungan berarti menyelamatkan bahasa dan kebudayaan. Menyelamatkan bahasa termasuk hal penting. Kepekaan peneliti dapat menangkap suasana ekologis yang terkadang berupa situasi lingkungan yang porak-poranda, penuh dengan sampah, dan tata ruang yang semakin amburadul. Selanjutnya, keadaan alam yang nyaman, tenteram, damai, dan memberikan inspirasi untuk hidup lebih baik. Memang banyak sekali fakta lingkungan yang perlu diselamatkan yang kurang sejalan dengan hati nurani.

Salah satu yang membuat ketidakseimbangan antara manusia dengan alamnya, yaitu penggunaan racun kimia untuk tumbuhan atau biasa disebut herbisida. Herbisida ini digunakan untuk memberantas tanaman-tanaman pengganggu atau sering juga disebut gulma, seperti kolonjono, paitan, kerisan, kucingan, tempuyung, kolomento, paku, putian dan lain-lain. Herbisida yang banyak digunakan merupakan berasal dari bahan kimia toksikan yang unik karena dalam penggunaannya, herbisida ditambahkan atau dimasukkan secara sengaja ke dalam lingkungan dengan tujuan untuk membunuh beberapa bentuk kehidupan (Keman, 200I). Seharusnya herbisida hanya berfungsi secara eksplisit pada suatu organisme tertentu yang dikehendaki saja dan tidak kepada organisme lain yang bukan sasaran. Akan tetapi, kenyataannya, herbisida sudah memberangus setiap organisme yang ada di hadapannya termasuk juga manusia dan organisme lain yang masih diperlukan oleh lingkungan. Sebenarnya penggunaan herbisida dapat dicegah dengan cara penerapan sistem pertanian yang disiplin dan terukur atau penggunaan racun yang alami, sehingga banyak organisme yang dapat terselamatkan, seperti mengembangkan musuh predatornya seperti gulma paitan, bayem-bayeman dan kolonjono yang dapat dimanfaatkan untuk pakan ternak lembu dan kambing, sedangkan seperti kiambang yang dapat digunakan untuk melindungi ikan sekaligus memberi pakan ikan.

Selanjutnya, setiap bahasa hadir dan hidup bersama penuturnya dalam suatu ruang dan waktu tertentu (Mbete, 2009), begitu juga dengan bahasa Jawa yang ada di Perkebunan Fajar Agung. Bahasa Jawa yang ada di Perkebunan Fajar Agung hidup bersama penuturnya di Desa Bengabing, Kecamatan Pegajahan, Kabupaten Serdang Bedagai. Masyarakat di desa ini sangat akrab dengan nama-nama gulma dalam bahasa Jawa karena ada kaitannya antara pekerjaan dengan gulma-gulma tersebut, namun masyarakat tidak menyadari bahwa pihak perkebunan sudah banyak melakukan pengrusakan dengan menggunakan herbisida dan pembersihan di lahan sawit. Padahal, tindakan tersebut dapat mengganggu keberadaan organisme yang sebenarnya tidak mengganggu tanaman yang produktif seperti gulma paku dan kacangan yang sebenarnya dapat dikembangbiakkan secara baik untuk kebaikan tanaman beserta kualitas lahan perkebunan.

Keberlangsungan situasi yang terjadi seperti ini yang secara terus-menerus dilakukan maka akan berdampak pada perubahan tingkat pemahaman dan kebertahanan leksikon dalam bahasa Jawa pada nama-nama tumbuhan yang dianggap sebagai gulma. Kehilangan pengetahuan tentang leksikon ini berdampak pada perubahan dan pergeseran bahasa, sehingga masyarakat meninggalkan bahasanya. Hal ini sejalan dengan (Rafael dan Ate, 2020) bahwa bahasa dikatakan mengalami pergeseran ketika suatu masyarakat mulai meninggalkan bahasa tradisionalnya (bahasa daerah atau bahasa ibu). Berdasarkan asumsi tersebut, perlu kiranya dilakukan pemertahanan bahasa daerah guna mencegah punahnya bahasa- 
bahasa daerah di Indonesia, seperti motto Badan Pembinaan dan Pengembangan Bahasa "utamakan bahasa Indonesia, lestarikan bahasa Daerah, dan kuasai bahasa Asing."

Berkaitan dengan pemertahanan bahasa dan perubahan penggunaan bahasa, (Thomason, 20II) mengungkapkan bahwa kontak bahasa umumnya menciptakan perubahan bahasa, baik separuh atau keseluruhan. Sementara itu, Wirianta dan Umiyati (2016) mengatakan bahwa kontak bahasa menciptakan masyarakat penutur yang bilingual ataupun multilingual. Selanjutnya ketika dua atau lebih bahasa bertemu, kontak tidak dapat dimungkiri lagi. Satu dari tiga hal bisa saja terjadi, yakni pemertahanan bahasa, pergeseran bahasa, atau kepunahan bahasa. Keadaan masyarakat penutur masih menggunakan bahasanya sendiri dan eksis dalam penggunaannya adalah situasi pemertahanan bahasa. Salah satu wujud pemertahanan bahasa ialah dalam ranah khazanah lingual. Sapir mengatakan bahwa jika kekayaan bahasa dalam berbagai levelnya merupakan gambaran tentang kekayaan budaya dan kekayaan lingkungan alam melalui leksikon yang diciptakankan (Fill, 200I). Demikian pun dalam bahasa Jawa, kekayaan leksikon kegulmaan mendeskripsikan kekayaan alam, keberagaman aktivitas yang melingkupi penuturnya dalam berkebun, dan kearifan lokal penuturnya. Kekayaan leksikon kegulmaan tentu saja harus disertai dengan pelestariannya agar tidak tersisihkan, hilang, dan terganti oleh padanan leksikon dari bahasa lain.

Pemertahanan bahasa menurut Fishman (1972) ditentukan oleh ideologi nasional dalam masyarakat atau ditentukan paling sedikit pada ideologi yang dimiliki masyarakat yang mempertahankan situasi sosialnya untuk melawan perubahan yang hadir. Adanya pemahaman tentang perlunya pemakaian bahasa daerah dalam masyarakat penutur bahasa daerah tertentu menyokong terlaksananya pemertahanan bahasa atau seperti yang dipetakan Fishman, (1972) pemertahanan bahasa terjadi pada masyarakat yang dapat mempertahankan bahasa hanya pada fungsi dan ranah tertentu. Pengidentifikasian pemertahanan bahasa menurut (Wharton, 2005) ada 3 topik, yang meliputi: (I) kebiasaan menggunakan bahasa daerah dalam berkomunikasi; (2) proses psikologi, sosial dan budaya dan hubungan mereka terhadap stabilitas atau perubahan dalam kebiasaan menggunakan bahasa; (3) perilaku terhadap bahasa, termasuk pada perilaku sikap dan perilaku kognitif. Selain itu, (Spolsky, 2009) membagi dimensi untuk menganalisis pemertahanan bahasa, yaitu dimensi ekonomi, dimensi politik, dimensi institusi, dimensi demografi, dimensi sikap, dimensi pendidikan, dan dimensi sosiokultural. Menurut Mardikantoro (2016) penggunaan bahasa bukan hanya ditentukan oleh faktor linguistik saja, melainkan juga faktor-faktor nonlinguistik. Faktor linguistik berhubungan dengan kebahasaan, sedangkan faktor non-linguistik, berkaitan dengan faktor sosial dan faktor situasional. Pemertahanan bahasa dalam masyarakat Manggarai dikaji dari dua faktor, yakni faktor linguistik dan non-linguistik. Faktor linguistik merujuk pada teori (Fishman, 1972) dan faktor non-linguistik merujuk teori (Spolsky, 2009).

Adapun penelitian yang bersinggungan atau berkaitan dengan tema pemahaman terhadap leksikon ini telah dibahas oleh tiga peneliti sebelumnya, sehingga penelitian tersebut dapat digunakan sebagai rujukan, perbandingan dan juga pertimbangan dalam penelitian ini, yaitu Rajistha (2016) mengenai Beblaba dan bahasa Bali dalam perspektif ekolinguistik". Hasil penelitian secara empiris, berdasarkan data angka-angka dalam bentuk persen, menunjukkan bahwa pemahaman gabungan tiga generasi dari sebelas leksikon flora tersebut. Hasilnya menunjukkan bahwa leksikon maritim secara keseluruhan masih bertahan dalam aktivitas sehari-hari. Perbedaan dengan penelitian sebelumnya adalah umur para responden yang diambil sebagai sumber data yaitu I5--20 tahun, dewasa usia 2I-- 45, dan tua usia $\geq 46$ tahun. Di sisi lain juga terlihat dari penggunaan leksikon flora, fauna dan aktivitas kemaritiman yang diujikan kepada masing-masing sepuluh responden masih bertahan pada kalangan usia tersebut, sedangkan penelitian ini mengambil data dari para responden yang berumur 25-45 tahun dan usia kedua 46-60 tahun terhadap leksikon kegulmaan.

Penelitian mengenai "Khazanah leksikon kelautan dalam bahasa Melayu dialek Sukadana" yang dilakukan oleh (Sari, Rabi’ul, dan Syahrani, 2019). Hasil penelitiannya adalah Bahasa Melayu Sukadana untuk remaja usia I5-20 tahun, dewasa 2I-45 tahun, dan usia $\geq 46$ tahun selama 8I leksikon dari hasil penelitian pemahaman leksikon Bahasa bahari dalam bahasa Melayu Sukadana masih bertahan di antara usia tersebut. Perbedaan dengan penelitian sebelumnya adalah menggunakan metode kualitatif yang 
mendeskripsikan kata-kata tertulis atau lisan dari orang-orang atau perilaku yang diamati, sedangkan penelitian ini menggunakan metode kualitatif yang disokong berupa perhitungan hasil responden secara kuantitatif. Selanjutnya penelitian dari (Kardi, Madeten, dan Syahrani, 2019) mengenai "Leksikon perpadian dalam masyarakat Dayak Jalai di Kabupaten Ketapang” pemahaman masyarakat Dayak Jalai terhadap leksikon perpadian masih bertahan dengan tingkat persentase rata-rata 89,83\%. Perbedaan dengan penelitian ini yaitu penelitian sebelumnya bersumber data dari sebuah teks deskripsi dan prosedur pada kurikulum 2013 SMP kelas VII semester I melalui SK 3.I. Walaupun sumber datanya agak sedikit berbeda, tetapi masih relevan untuk sebuah penelitian kualitatif, sedangkan penelitian ini memakai sumber data kualitatif yang disokong data kuantitatif yang dijaring melalui sebuah angket.

Adapun penelitian yang bersinggungan atau berkaitan dengan tema faktor tingkat kebertahanan pemahaman terhadap leksikon ini telah dibahas oleh beberapa peneliti sebelumnya, sehingga penelitian tersebut dapat digunakan sebagai rujukan, perbandingan dan juga pertimbangan dalam penelitian ini, yaitu (Thatsanai, 2017) mengenai "Faktor Pendorong untuk Hidup Berdampingan dengan Orang Thailand: Studi Kasus Pekerja Migran di Pathum Thani, Thailand. Hasil penelitian ini mengungkap bahwa kebertahanan bahasa di Thailand dipengaruhi oleh tiga faktor pertama yang dimiliki skor tertinggi adalah (I) faktor bahasa dan komunikasi; (2) faktor hukum dan keamanan; (3) faktor agama. Kemudian Amano et al. (20I4) mengungkapkan dalam artikelnya yang berjudul "Global distribution and drivers of language extinction risk. Hasil penelitian ini mengatakan bahwa penurunan penggunaan bahasa dipengaruhi oleh iklim yang mengakibatkan perubahan jumlah penduduk yang memengaruhi para pengguna bahasanya. Semakin banyak penduduknya maka akan semakin terancam bahasa-bahasa yang kecil penuturnya. (Mufwene, 2002) dalam artikelnya yang berjudul "Colonization, globalization and the plight of 'weak' languages" mengungkapkan bahwa kolonisasi dan globalisasi sebagai penyebab dari musnahnya suatu bahasa. Penelitian Ghazali, Jaafar, dan Radzi (2019) mengenai "Peralihan bahasa Cham dalam masyarakat Cham di Malaysia: Analisis sosiolinguistik”. Hasil penelitian menunjukkan bahwa secara empiris, faktor peralihan bahasa disebabkan oleh penggunaan bahasa dalam domain kekeluargaan, penggunaan bahasa dalam domain kejiranan, dan penggunaan bahasa dalam domain pekerjaan. Kemudian penelitian Shin, Mangku, dan Collins (2018) mengenai "Pemilihan Bahasa Komuniti Penan Muslim di Sarawak". Hasil penelitian ini menunjukkan bahwa secara empiris, masyarakat suku pribumi Borneo Barat bila mereka memeluk agama Islam, mereka harus menggunakan bahasa melayu. Jadi faktor kebergeseran bahasa ibu ke bahasa melayu dipengaruhi oleh agama Islam. Penelitian (Widyanigrum, 2018) mengenai "Campur kode siaran Radio Most FM penyiar di Kota Malang” mengalami peralihan bahasa Inggris dan Jawa. Selain itu, dipengaruhi oleh beberapa faktor, yaitu supaya terkesan santai atau akrab dengan pendengar; lebih populer, bergengsi, dan singkat. Bila dibandingkan dengan penelitian terdahulu, faktor kebertahanan dalam penelitian ini dipengaruhi oleh dua faktor, yaitu faktor linguistik dan faktor non-linguistik. Begitu juga dengan penelitian yang dilakukan oleh (Adliza, Oktavianus, \& Usman, 202I; Genua, 2018; Jupitasari, 202I; Kurniawan, Usman, \& Iswary, 2019; Mahayana, Sukiani, Suwendri, \& Winaya, 2019; Ndruru, 2020; Santoso, 2017; Sinungharjo, 2020; Suktiningsih, 2016) sejalan dengan penelitian penulis dan menjadi bukti masih tetap pentingnya kajian pemertahanan bahasa tersebut.

Oleh karena itu, berdasarkan uraian latar belakang tersebut, maka penelitian ini bertujuan untuk menjelaskan faktor yang memengaruhi tingkat pemahaman masyarakat Jawa terhadap leksikon kegulmaan di Perkebunan Fajar Agung. Hasil dari penelitian ini diharapkan dapat menjadi rekomendasi kepada Pemerintah Kabupaten Serdang Bedagai dalam perlunya pemertahanan bahasa Jawa di Serdang Bedagai, sebagai bentuk warisan budaya yang diturunkan dari waktu ke waktu. Selain itu, hasil penelitian diharapkan menjadi bahan evaluasi diri kepada Pemerintah Kabupaten Serdang Bedagai yang menganggap penggunaan bahasa Jawa di globalisasi saat ini sudah tidak sesuai lagi. Selanjutnya penelitian ini juga dapat menjadi bahan acuan untuk para peneliti selanjutnya yang melakukan penelitian serupa di bidang kajian ekolinguistik. 


\section{METODE}

Sesuai karakter masalah yang ditelaah, penelitian ini menggunakan pendekatan kualitatif yang didukung berupa perhitungan hasil responden secara kuantitatif. Menurut Syamsuddin (2015) penelitian kualitatif adalah suatu pendekatan yang juga disebut pendekatan investigasi karena biasanya peneliti mengumpulkan data dengan cara bertatap muka secara langsung dan berinteraksi dengan orang-orang ditempat penelitian. Menurut Sugiono (2015) metode kuantitatif dinamakan metode tradisional, karena metode ini sudah cukup lama digunakan, sehingga sudah menjadi tradisi sebagai metode untuk penelitian. Data tingkat pemahaman leksikon kegulmaan diperoleh melalui angket. Angket berisi data daftar leksikon kegulmaan yang sebelumnya diperoleh melalui wawancara kepada informan kunci. Informan kunci ini adalah penutur bahasa Jawa yang memiliki keterampilan berbahasa etnis yang masih kental sekaligus tinggal di Perkebunan Fajar Agung.

Selain menggunakan informan kunci, penelitian ini juga menggunakan dua orang informan pendukung. Informan dalam penelitian ini mengikuti kriteria Mahsun (I995) yaitu berjenis kelamin pria atau wanita, bersuku Jawa, berusia 25-65 tahun, orang tua, istri, atau suami informan lahir dan dibesarkan di desa itu, serta jarang atau tidak pernah meninggalkan desanya, berstatus sosial menengah dengan harapan tidak terlalu tinggi mobilitasnya, memiliki kebanggaan terhadap isolek dan masyarakat isoleknya, informan merupakan penutur asli, sehat jasmani dan rohani. Dalam menjaring data, angket disebar kepada 26 orang responden dengan usia 25-45 tahun dan 43 responden dengan usia 46-60 tahun di Perkebunan Fajar Agung. Selanjutnya, angket diberikan tiga kategori pilihan jawaban yang harus dicentang oleh responden. Ketiga kategori pilihan jawaban itu adalah $\mathrm{T}$ (Tahu: bermakna responden tahu tentang leksikon tersebut); kemudian kategori TT, PM (Tidak Tahu, Pernah Mendengar: bermakna responden tidak mengetahui referen dari leksikon tersebut, mereka hanya pernah mendengar, tetapi tidak mempunyai pengalaman menyebutkan atau menunjukkun referennya); TT, TPM (Tidak Tahu, dan Tidak Pernah Mendengar: bermakna responden sama sekali tidak memiliki pengalaman terkait leksikon tersebut, baik menyebutkan maupun mendengarkan). Setelah diperoleh hasil angket, kemudian dihitung untuk memperoleh persentase tingkat pemahaman mereka terhadap leksikon-leksikon yang diujikan tersebut. Berdasarkan angka persentase tersebut kemudian dideskripsikan. Adapun tekniknya seperti penjelasan sebagaimana Tabel I.

Tabel I

Angket Pengujian Pemahaman Masyarakat Jawa terhadap Leksikon Kegulmaan di Perkebunan Fajar Agung, Kecamatan Pegajahan, Kabupaten Serdang Bedagai

\begin{tabular}{llllllll}
\hline \multirow{2}{*}{ No } & \multirow{2}{*}{ Leksikon } & \multicolumn{2}{c}{ Kelompok Usia I (25-45 Tahun) } & \multicolumn{2}{c}{ Kelompok usia II (46-60 Tahun) } \\
\cline { 2 - 7 } & & T & TT, PM & TT, TPM & T & TT, PM & TT,TPM \\
\hline I & & & & & & \\
\hline 2 & & & & & \\
\hline
\end{tabular}

$\begin{array}{lll}\text { Keterangan } & & \\ \text { T } & : & \text { Tahu } \\ \text { PM } & : \text { Pernah Mendengar } \\ \text { TT } & : \text { Tidak Tahu } \\ \text { TPM } & : \text { Tidak Pernah Mendengar }\end{array}$

Data hasil angket kemudian dihitung menggunakan rumus:

$$
P=\frac{f}{n} \times 100 \%
$$

Keterangan

$\mathrm{P}$

$:$ jumlah temuan

n : total responden

Sumber (Sujana, 2010) 
Dalam menganalisis data, jawaban dari setiap responden disimbolkan dalam bentuk angka kemudian angka-angka tersebut dijumlahkan dan diubah ke dalam bentuk persen, sehingga akan terlihat pemahaman masyarakat Fajar Agung, Kecamatan Pegajahan, Kabupaten Serdangbedagai. Kemudian untuk menganalisis rumusan masalah yang kedua yaitu dengan metode kualitatif. Hasil persentase tingkat pemahaman dua kelompok tersebut dijadikan acuan dalam wawancara dengan informan kunci untuk memeroleh informasi tentang faktor-faktor yang memengaruhi tingkat pemahaman leksikon kegulmaan Masyarakat Fajar Agung, Kecamatan Pegajahan, Kabupaten Serdangbedagai. Dengan demikian, metode analisis data yang digunakan adalah metode deskriptif kualitatif dan disokong oleh data kualitatif.

\section{HASIL DAN PEMBAHASAN}

\section{Tingkat Pemahaman Leksikon Kegulmaan}

Berdasarkan hasil wawancara kepada informan kunci, diperoleh leksikon kegulmaan pada masyarakat Jawa di Perkebunan Fajar Agung, Kecamatan Pegajahan, Kabupaten Serdang Bedagai sebanyak 75 leksikon. Leksikon tersebut diuraikan dalam Tabel 2, serta uraian di bawah ini hanya sebagai contoh.

Tabel 2

Leksikon Kegulmaan Pada Masyarakat Jawa di Perkebunan Fajar Agung,

Kecamatan Pegajahan, Kabupaten Serdang Bedagai

\begin{tabular}{cccc}
\hline No & Leksikon & Istilah Latin & Bahasa Indonesia \\
\hline I & Amplasan & Asystasia gangetica Axonopus & rempelas \\
2 & Anak kayu & - & - \\
3 & Aseman & Polygonum chinense & asaman \\
4 & Bandotan & Ageratum conyzoides L & bandotan \\
5 & bayem duri & Amaranthus spinosus & bayam duri \\
\hline
\end{tabular}

\section{Perbandingan Hasil Pemahaman Kelompok Usia I dan Usia II}

Selanjutnya, perbandingan data hasil angket pemahaman responden Masyarakat Jawa kelompok usia I (25-45 Tahun) dan usia II (46-60 Tahun) terhadap leksikon kegulmaan di Perkebunan Fajar Agung, Kecamatan Pegajahan, Kabupaten Serdang Bedagai disajikan dalam Tabel 3.

Tabel 3

Perbandingan Tingkat Pemahaman Masyarakat Jawa Kelompok Usia I dan Usia II Terhadap Leksikon Kegulmaan di Perkebunan Fajar Agung, Kecamatan Pegajahan, Kabupaten Serdang Bedagai

\begin{tabular}{ccccccc}
\hline \multirow{2}{*}{ Leksikon } & \multicolumn{3}{c}{ Kelompok Usia I (25-45 Tahun) } & \multicolumn{3}{c}{ Kelompok usia II (46-60 Tahun) } \\
\cline { 2 - 7 } & T & TT, PM & TT, TPM & T & TT,PM & TT,TPM \\
\hline Leksikon Gulma & $83,53 \%$ & $5,07 \%$ & I I,38\% & $83,15 \%$ & $6,46 \%$ & I0,04\% \\
\hline
\end{tabular}

\section{Kelompok Usia I (25-46 Tahun)}

Berdasarkan Tabel 3 dapat dijelaskan tingkat pemahaman MJFA kelompok usia I terhadap leksikon gulma pada kategori $\mathrm{T}(\mathrm{T} a \mathrm{a} u)$ bermakna responden mengerti, mengenal, pernah melihat, pernah menyebutkan, dan mengalami atau punya pengalaman menggunakan/menyebutkan leksikon tersebut sebanyak I.629JP persentasenya mencapai 83,53\%. Kategori TT, PM (Tidak Tahu, Pernah Mendengar)yang bermakna responden tidak mengerti, tidak mengenal, tidak pernah melihat, tidakpernah menyebutkan, tetapi pernah mendengarsebanyak 99 JP persentasenya mencapai 5,07\% . Pada kategori TT, TPM (Tidak Tahu, Tidak Pernah Mendengar)bermakna responden sama sekali tidak mengerti, tidak mengenal, tidak mengetahu, tidak pernah menyebutkan, dan bahkan tidak pernah mendengar dan tidak memiliki pengalaman berhubungan dengan leksikon tersebut diperoleh hasil sejumlah $222 \mathrm{JP}$ dengan persentase II,38\%.

Hasil analisis data ini menunjukkan bahwa leksikon gulma masih dikenal oleh MJFA pada kelompok usia I (25-45 tahun) melalui kategori T. Hal ini disebabkan oleh penutur kelompok usia I (2545 tahun) yang pekerjaannya dominan sebagai karyawan kebun sehingga dapat diperoleh persentase 
tingkat pemahaman yang tinggi. Selain itu, para kategori TT, PM dan TT,TPM ini memiliki angka yang memang tidak terlalu tinggi namun dapat disoroti bahwa ada leksikon-leksikon yang tidak dikenal atau tidak terwarisi oleh responden kelompok usia I ini karena penggunaan istilah gulma yang berbeda-beda di satu perkebunan dengan perkebunan yang lainnya sehingga responden tidak mengenalinya. Hal ini bila ditinjau dari segi linguistik, masyarakat perkebunan khususnya masyarakat Jawa adalah orang-orang yang sesuka hati menamai sebuah gulma (arbitrer).

\section{Kelompok Usia II (46-60 Tahun)}

Berdasarkan Tabel 3 dapat dijelaskan bahwa tingkat pemahaman MJFA kelompok usia II (4660 tahun) terhadap leksikon gulma pada kategori T(Tahu) bermakna responden mengerti, mengenal, pernah melihat, pernah menyebutkan, dan mengalami atau punya pengalaman menggunakan/menyebutkan leksikon tersebut sebanyak 2.690JP persentasenya mencapai 83,I5\%. Kategori TT, PM (Tidak Tahu, Pernah Mendengar) yang bermakna responden tidak mengerti, tidak mengenal, tidak pernah melihat, tidak pernah menyebutkan, tetapi pernah mendengar sebanyak $209 \mathrm{JP}$ persentasenya mencapai $6,46 \%$. Pada kategori TT, TPM (Tidak Tahu, Tidak Pernah Mendengar) bermakna responden sama sekali tidak mengerti, tidak mengenal, tidak mengetahui, tidak pernah menyebutkan, dan bahkan tidak pernah mendengar dan tidak memiliki pengalaman berhubungan dengan leksikon tersebut diperoleh hasil sejumlah 325 JP dengan persentase I0,04\%. Dengan demikian, secara keseluruhan pemahaman leksikon gulma pada MJFA untuk generasi usia 46-60 tahun jumlah pemahaman yang paling tinggi adalah pada kategori (T) Tahu dengan jumlah pemahaman 2.690 (83,15\%) dan kategori TT, PM (Tidak Tahu, Pernah Mendengar) memperoleh persentase pemahaman terendah dengan jumlah pemahaman 209 dengan persentase (I0,04\%).

Hasil analisis data ini menunjukkan bahwa leksikon gulma masih dikenal oleh MJFA pada kelompok usia II (46-60 tahun) melalui kategori T. Hal ini disebabkan oleh penutur kelompok usia II (46-60 tahun) yang pekerjaannya dominan sebagai karyawan kebun, sehingga dapat diperoleh persentase tingkat pemahaman yang tinggi. Selain itu, para kategori TT, PM dan TT,TPM ini memiliki angka yang memang tidak terlalu tinggi, namun dapat disoroti bahwa ada leksikon-leksikon yang tidak dikenal atau tidak terwarisi oleh responden kelompok usia II. Hal ini dikarenakan penggunaan istilah gulma yang berbeda-beda di satu perkebunan dengan perkebunan yang lainnya, sehingga responden tidak mengenalinya. Hal ini bila ditinjau dari segi linguistik, masyarakat perkebunan khususnya masyarakat Jawa adalah orang-orang yang sesuka hati menamai sebuah gulma (arbitrer). Selain itu, ada beberapa responden yang hanya sebagai ibu rumah tangga atau pekerjaannya tidak banyak bersentuhan dengan pengendalian dan pemberantasan gulma.

\section{Faktor Kebertahanan Leksikon Kegulmaan Pada MJFA}

Kebertahanan leksikon kegulmaan pada MJFA bergantung pada sikap penuturnya kepada bahasa atau sikap bahasa. Sikap bahasa merupakan segala jenis tingkah laku tentang bagaimana bahasa dinyatakan termasuk sikap-sikap dalam usaha perencanaan dan pelestarian bahasa (Fasold, 200I). Sikap bahasa pada umumnya berhubungan dengan faktor linguistik dan non-linguistik. Faktor linguistik berhubungan dengan bahasa itu sendiri. Faktor linguistik ini sejalan dengan (Fishman, 1972), sedangkan faktor nonlinguistik berhubungan dengan keadaan eksternal bahasa yang secara langsung, maupun tidak langsung menjadi penyebab kebertahanan itu (Spolsky 2009).

\section{Faktor Linguistik}

Faktor linguistik adalah hal fundamental dalam kebertahanan bahasa. Menurut Fishman (1972), pemertahanan dapat terbentuk bila adanya kebiasaan pemakaian bahasa daerah dalam berkomunikasi, melalui proses psikologi, dan sikap bahasa. Berikut adalah faktor linguistik kebertahanan leksikon kegulmaan pada MJFA 


\section{Tendensi Masyarakat Jawa Terhadap Bahasa Jawa}

Jika dilihat persentase pemahaman MJFA berdasarkan kelompok usia I (25-45 tahun) dan kelompok usia II (46-60 tahun), terhadap leksikon kegulmaan dengan persentase pada kategori usia I (25-45) mencapai 83,53\%, serta kelompok usia II (46-60 tahun) mencapai 83,I5. Tingginya persentase tersebut tentunya tidak luput dari faktor tendensi MJFA terhadap bahasa Jawa itu sendiri. Walaupun semakin baiknya tingkat pendidikan yang sudah mulai melunturkan semangat MJFA dalam menggunakan bahasa Jawa, masyarakat Jawa khususnya masyarakat kategori usia I (25-45) masih tetap memahami bahasa Jawa karena pewarisan bahasa dari orang tua mereka. Hal ini dapat dilihat pada wawancara dengan informan berikut ini.

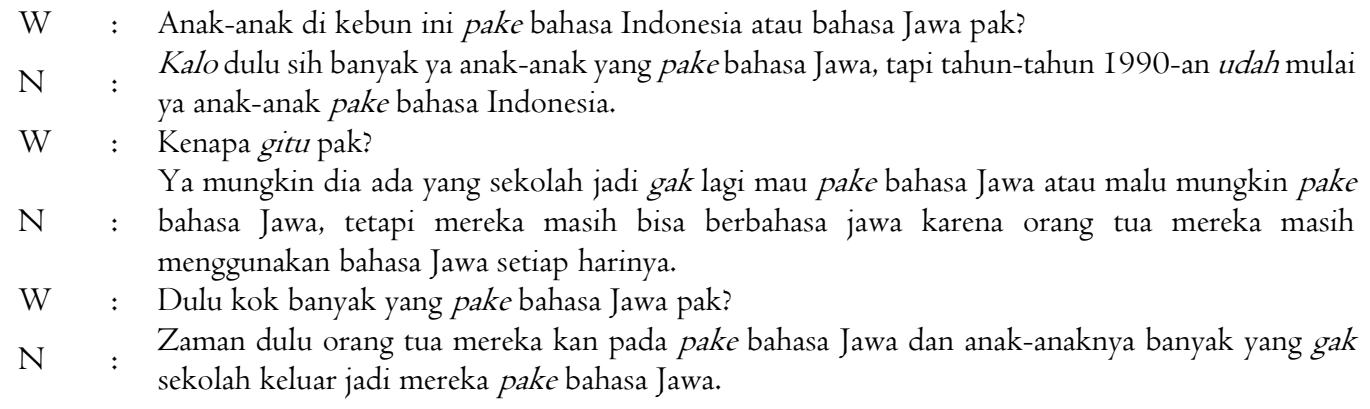

Selain itu, dominasi suku Jawa di Perkebunan Fajar Agung juga menentukan tendensi MJFA terhadap bahasa Jawa itu sendiri. Hal ini dapat dilihat pada wawancara dengan informan berikut ini.

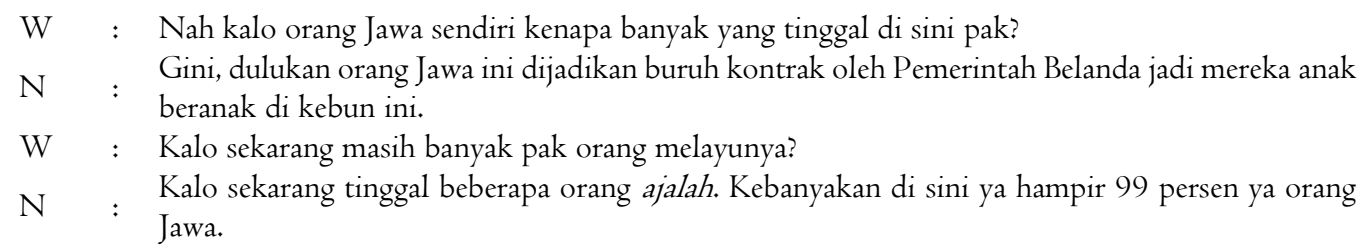

Dominasi suku Jawa di perkebunan ini sangat kuat dan ditambah lagi dengan para generasi umur (46-60 tahun) yang masih menggunakan bahasa Jawa sehari-hari dengan anak-anak mereka. Hal ini membuat kebertahanan pengetahuan MJFA terhadap leksikon kegulmaan tetap terjaga dengan baik. Namun, tendensi ke arah melunturnya bahasa Jawa yang disebabkan oleh bahasa Indonesia atau faktor lainnya juga ada walaupun angkanya hanya $12,67 \%$.

\section{Faktor Non-linguistik}

Faktor non-linguistik juga menjadi penyebab kebertahanan sebuah bahasa. Faktor non-linguistik berkaitan dengan faktor-faktor eksternal atau bukan bahasa yang memberikan dampak terhadap kebertahanan bahasa. Hal ini sesuai dengan teori Spolsky (2009), yang menyatakan bahwa faktor-faktor non-linguistik kebertahanan leksikon kegulmaan pada MJFA adalah sebagai berikut.

\section{Perilaku Konservatif MJFA Terhadap Gulma}

Dalam suatu wawancara jarak jauh, Mbete (2009) menyatakan perilaku konservatif sebagai perilaku atau tindakan yang menjaga, merawat, juga menggunakan secara terukur agar tidak punah dan tetap awet. Perilaku tersebut dapat dilihat pada cara pihak perkebunan melindungi gulma. Bapak $\mathrm{N}$ menuturkannya berikut ini. 
Kalau setiap kebun itu beda-beda, kenapa? Karena itu tergantung sama ketinggian permukaan tanah, itu satu yang kedua itu soal efisiensi, mengingat biaya yang cukup besar untuk pengendalian dan pemberantasan gulma ini, pihak kebun biasanya memangkas biaya melalui pengurangan tindakan pemberantasan. Misalnya ada kebun yang hanya memiliki I jenis gulma saja pada saat masa tanam berkisar 0-4 tahun contohnya gulma kacangan. Jadi di masa-masa itu hanya gulma kacanganlah yang hidup, gulma lainnya dimusnahkan. Berbeda dengan kebun

$\mathrm{N}$ : bengabing ini, bila tanaman pada umur 0-4 tahun tidak ada gulma yang dispesialkan karena memang untuk melakukan seperti kebun yang menerapkan hanya I gulma saja itu membutuhkan biaya yang sangat besar ya, karena gulma kacangan ini sangat bagus untuk tanah bagi tanaman yang baru tumbuh. Tapi kebun bengabing tidak melakukan itu karena biaya bibit kacanganya, pembibitannya, dan juga perwatannya juga. Nah kacangan itu bisa menjadi gulma lagi bila tidak ada pengendalian nantinya.

Keterbatasan keuangan atau efisiensi biaya sebenarnya tidak dapat dipandang sebagai kekurangan atau lemahnya manajemen kebun, tetapi ada sisi baik dari hal ini karena secara tidak langsung akan menjaga keseimbangan lingkungan alam. Hal ini dapat dilihat pada kutipan kalimat berikut.

Berbeda dengan kebun bengabing ini, bila tanaman pada umur O-4 tahun tidak ada gulma yang dispesialkan karena memang untuk melakukan seperti kebun yang menerapkan hanya I gulma saja itu membutuhkan biaya yang sangat besar ya, karena gulma kacangan ini sangat bagus untuk tanah bagi tanaman yang baru tumbuh. Tapi kebun bengabing tidak melakukan itu karena biaya bibit kacanganya, pembibitannya, dan juga perwatannya juga.

Bila dikaitkan dengan perlindungan terhadap gulma yang dapat menjaga keseimbangan alam di perkebunan ini, dapat kita lihat pada kutipan wawancara berikut ini.

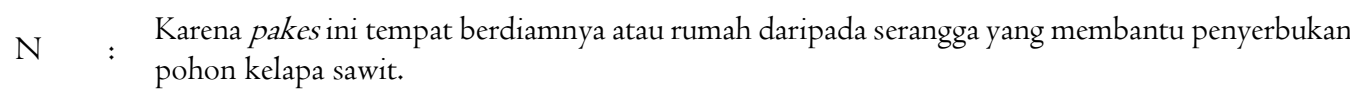

Perilaku konservatif guyub tutur terhadap lingkungan yang menyiratkan kedekatan dan keakraban, baik dari segi dimensi biologis maupun dimensi sosiologis. Hubungan yang baik antara masyarakat (dimensi sosiologis) yang tinggal di sekitar perkebunan dengan pihak kebun melalui pengilegalan ngangon kambing. Perilaku konservatif ini digambarkan melalui kutipan wawancara berikut ini.

Wah ya masih banyak, bahkan diperbolehkannyangangon ini merupakan bentuk kepedulian dan kontribusi pihak kebun kepada masyarakat yang tinggal di sekitar Perkebunan Fajar Agung.

$\mathrm{N}$ : Misalnya masyarakat di Desa Lestari, petuaran, melati, karang kecepit, karena kalo tidak dibuat begini nanti ribut lagi kayak tahun 1997.

Dampak dari perilaku konservatif tersebut memberikan dampak timbal balik yang baik kepada masyarakat. Hal ini dapat dilihat dari kutipan wawancara berikut ini.

Wah ya ada, kayak pakes, kangkung, bayem, genjer. Itulah dia yang biasa diambil anak-anak

$\mathrm{N} \quad$ : angon kambing. Makanya ini semua kalo diberantas rugi juga masyarakat karena banyak yang bisa dimanfaatkan.

Ketahanan menjaga lingkungan melalui peminimalan pemberantasan gulma-gulma dan memperlakukan gulma sebagai bagian dari kehidupan masyarakat tersebut, kondisi ini jelas mempertahankan leksikon gulma dalam bahasa Jawa. Ini berarti biota yang berada dalam lingkungan perkebunan itu dapat bertahan. Bila biota-biota itu bertahan maka secara otomatis leksikon-leksikon gulma itu juga dapat bertahan. 


\section{Adaptasi Fisiologi Gulma Terhadap Herbisida}

Salah satu bentuk adaptasi terhadap lingkungan yaitu adaptasi fisiologi. Adaptasi fisiologi adalah penyesuaian diri makhluk hidup melalui fungsi kerja organ-organ tubuh supaya bisa bertahan hidup. Penyesuaian diri inilah yang dilakukan oleh gulma di lingkungan perkebunan. Penyesuaian ini sering disebut sebagai resistensi. Resistensi ini diakibatkan oleh konsekuensi pemakaian herbisida yang sama. Dalam pengukuhan Guru Besar bidang Pertanian USU, Tampubolon (2018) mengatakan bahwa konsekuensi dari pemakaian herbisida yang sama (sama jenis bahan aktif atau sama cara kerja) secara berulang-ulang dalam periode yang lama pada suatu areal maka ada dua kemungkinan masalah yang timbul pada areal tersebut; yaitu terjadi dominansi populasi gulma resisten-herbisida atau dominansi gulma toleran herbisida. Resistensi ini digambarkan melalui kutipan wawancara berikut ini.

Kita gak tau ya berapa kadar racun yang dipakai. Apa mungkin dikurangi jumlah takaran racunnya demi efisiensi pembiayaan atau memang rumputnya semakin lama semakin kebal. Kita

$\mathrm{N} \quad$ : juga gak tau. Tapi ada jugak itu jenis gulma yang bila disemprotkan racun sistemik tapi susah matinya, kayak gulma Lulangan itu. Tapi sekarang ini kan pihak perusahaan racun ya khususnya untuk gulma memang udah ada seperti spesifikasi untuk gulma yang resistensi ini. Namanya itu racun Optimus. Racun ini Cuma diperuntukkan untuk gulma seperti Lulangan itu tadi.

Pernyataan informan tersebut diperkuat dengan makalah (Tampubolon, 2018) yang berjudul konfirmasi resistensi eleusine indica terhadap glifosat pada perkebunan kelapa sawit di Kabupaten Langkat. Dalam makalah tersebut menjelaskan bahwa gulma Belulangatau lulangan salah satu spesies gulma yang sudah mengalami resistensi terhadap herbisida glifosat yaitu belulang (Eleuisine indica(L.) Gaertn). Gulma ini tergolong agresif karena pertumbuhannya yang kuat dan dapat menghasilkan produksi biji yang melimpah. Belulang dapat tumbuh mencapai 3 kaki atau I meter dan menyebar dengan memperbanyak diri melalui biji.

Sifat resistensi gulma ini bila dilihat dari sisi lingkungan hidup memang cukup mengerikan karena gulma-gulma tersebut sudah mulai terganggu dengan adanya aktivitas manusia. Apalagi dengan pengendalian yang berlebihan maka alam memiliki caranya sendiri untuk mempertahankan dirinya dan secara tidak langsung leksikon-leksikon pada gulma-gulma tersebut akan resisten juga terhadap perubahan lingkungan.

\section{Penggunaan Peralatan Tradisional Pengendalian dan Pemberantasan Gulma}

Sejak keberadaan manusia di muka bumi ini, mereka telah berusaha untuk memenuhi kebutuhankebutuhannya. Kebutuhan manusia tidak hanya menyangkut kebutuhan pokok seperti; makan, minum dan sebagainya. Akan tetapi, kebutuhan-kebutuhan lain yang lebih luas dan sempurna baik mengenai kualitas, kuantitas dan jenisnya yang dinamakan kebutuhan sekunder. Untuk kesejahteraan hidup manusia, pemenuhan kebutuhan pokok dari waktu ke waktu kebutuhan-kebutuhan manusia kian bertambah dan makin bervariasi sejalan dengan perkembangan zaman. Demikian pula manusia yang selalu dituntut untuk berusaha semaksimal mungkin dalam rangka pemenuhan kebutuhan hidupnya.

Di dalam usaha untuk mencukupi kebutuhan hidup, dengan kata lain mencari kemakmuran, manusia harus berusaha dan di antaranya ada yang langsung berhadapan dengan alam yang kerapkali tak sudi diajak untuk kompromi, dan tidak memberikan segala sesuatu dengan begitu saja. Salah satu yang dilakukan adalah dengan mengembangkan perekonomiannya dengan cara berproduksi yang erat hubungannya dengan distribusi sebagai tindak lanjut daripada produksi tersebut.

Di dalam usaha-usaha yang dilakukan untuk berproduksi dan mendistribusi hasil produknya, manusia membutuhkan berbagai peralatan mulai dari alat yang sederhana, hingga alat yang serba mekanis atau modern. Fakta umumnya mata pencaharian penduduk di daerah-daerah agraris mayoritas bergerak di sektor pertanian. Oleh sebab itu, peralatan produksi yang digunakan begitu pula peralatan distribusinya disesuaikan dengan kebutuhan daerah tersebut. 
Bagi Masyarakat Fajar Agung, keberadaan peralatan modern mulai menggeser penggunaan peralatan tradisional untuk pengendalian dan pemberantasan gulma di perkebunan. Peralatan tradisional masyarakat Perkebunan Fajar Agung yaitu parang babat, cangkul, cakar, dan sabit akan terus mengalami keterpinggiran fungsi dan perannya. Hal ini digambarkan melalui hasil wawancara berikut ini.
$\mathrm{N}$ : Ya kalo sekarang rata-rata ya udah banyak pakai alat modern ya karena pengendalian gulma ini khemis ya pakai racun kimia.

Peralatan-peralatan modern itu tidak seluruhnya mempunyai dampak yang positif tetapi ada juga sisi negatifnya. Tidak sepenuhnya peralatan modern dapat menuntaskan pekerjaan yang ada di perkebunan. Hal ini dapat dilihat melalui rekaman wawancara berikut ini.

O... tidak bisa. Alat-alat tradisional masih sangat berfungsi untuk mengerjakan hal-hal yang tidak mungkin bisa dikerjakan oleh alat-alat yang modern, misalnya objek yang dikerjakan bukan lahan yang harus dimekanis, maka lat-alat tradisional misalnya cangkul itu masih dipakai. Dan yang

$\mathrm{N} \quad$ : kedua, alat-alat modern itu akan meningkatkan jumlah pengangguran karena semua dapat dikerjakan dengan alat-alat modern itu. Jadi peran dari alat-alat tradisional ini gak bisa ditinggalkan.

Dampak tergesernya peralatan tradisional pengendalian dan pemberantasan gulma memang memiliki dampak secara ekonomis dan merusak tatanan dimensi sosial. Hal ini tampak pada kalimat yang digarisbawahi pada wawancara dengan informan itu. Peralatan tradisional yang dimanfaatkan baik pada pertanian sawah maupun ladang, sumber daya manusia masih tetap memegang peranan yang amat vital di dalam pengoperasiannya karena tenaga manusia yang menggerakkan alat-alat tersebut. Hal ini sejalan dengan penelitian yang dilakukan Ndruru, 2020 bahwa penggunaan alat tradisional masih menjadi prioritas utama bagi sebagian orang yang bekerja di perkebunan. Hal ini dikarenakan alat tradisional sudah mendarah daging dan sangat mudah dalam pemanfaatannya dibandingkan dengan peralatan modern.

Fungsi dan manfaat dari alat tersebut bukan hanya dilihat dari segi fungsi praktis dan efisiensi kerjanya, melainkan juga dipakai sebagai simbol dari kepatuhan terhadap leluhur atau generasi sebelum mereka, yang telah membuktikan daya dan hasil gunanya mulai waktu mengolah tanah, menanam, memelihara tanaman, memungut hasil, mengolah hasil produksi serta tata cara pendistribusiannya.

\section{Kesejahteraan Masyarakat Jawa Fajar Agung}

Industri perkebunan sekarang sudah tidak mengeksploitasi masyarakat, melainkan menjadikannya sebagai stakeholder yang semua haknya dilindungi peraturan perundang-undangan. Pemerintah pun mengatur sistem pengupahan yang disebut Upah Minimum Regional (UMR) dan fasilitas penunjang untuk para pekerja, seperti perumahan, kesehatan, dan pendidikan bagi para pekerja perkebunan. Status keanggotaan pada Serikat Pekerja Perkebunan juga diperlukan untuk menghindari adanya pekerja di bawah umur. Terkiat dengan kesejahteraan, hasil wawancara sesuai penelitian Kurniawan, Usman, \& Iswary, 2019, yang menyampaikan bahwa tingkat kesejahteraan bagi para pekerja di perkebunan selalu menjadi polemik tersendiri yang berkepanjangan.

Para pekerja ataupun staf di Perkebunan Fajar Agung sampai saat ini masih mendapatkan upah yang masih relatif kurang dan hanya cukup untuk makan saja, sementara upah yang ada belum dapat mengangkat kesejahteraan karyawan. Berikut ini adalah kutipan wawancara oleh informan.

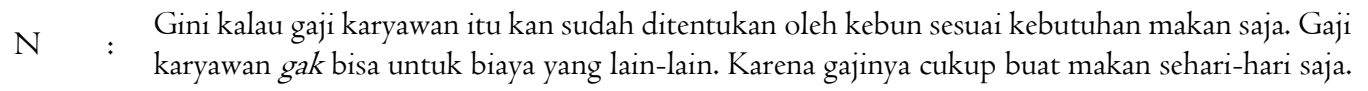

Walaupun upah kurang untuk menutupi kebutuhan lain selain makan, perusahaan tetap berusaha untuk bagaimana menyejahterakan karyawannya di luar upah pokok pekerjaan karyawan. Caranya yaitu perusahaan masih menerapkan sistem SKU (sejenis dengan PNS/ASN) dengan adanya pengangkatan 
SKU ini diharapkan kehidupan karyawan menjadi lebih baik. SKU ini menjamin kesehatan, mendapatkan bonus kerja per tahun, mendapatkan THR, dan jaminan pensiun. Berikut ini adalah kutipan wawancara dengan informan.

\footnotetext{
SKU ini sejenis sama PNS lah gitu. Jadi setiap karyawan dapat keistimewaan lah gitu, misalnya

$\mathrm{N}$ : dapat THR, bonus, dapat tunjangan kesehatan kalo sekarang BPJS kalo dulu jamsostek ya. Kalo misalnya pensiun nanti dapat pesangon dari kebun.
}

Status SKU dan segala manfaat yang didapat juga dirasa masih kurang karena sifatnya yang jangka panjang sementara kebutuhan jangka pendek dan menengah juga harus dipenuhi seperti kebutuhan perabot rumah tangga seperti televisi, alat komunikasi, kendaraan dan pendidikan juga harus dipenuhi. Itu semua membutuhkan biaya yang tidak mahal. Oleh karena itu, para karyawan diberi kesempatan untuk bekerja di luar jam kerjanya atau di luar pencapaian dengan upah di luar gaji pokok. Berikut ini adalah kutipan wawancara dengan informan.

W : Jadi bagaimana bila ada kebutuhan lain pak yang harus dibiayai? Nah, karyawan kebun ini kan punya jam kerja dan porsi kerja. Di kebun ini porsi kerja itu terbatas, misalnya gini kalo kita kerja di bagian panen buah misalnya. Targetnya IO kilo misalnya

$\mathrm{N}$ : sekali panen, nah rupanya hasil panennya hari itu melebihi target maka karyawan itu mendapatkan uang insentif diluar gaji biasanya. Misalnya lagi kalo dia staf kantor, kalau lembur maka akan diberi juga insentif. Nah dari situlah karyawan dapat membiayai anak sekolah, beli kereta misalnya atau perabot rumah tangga.

W : Jadi Cuma cukup untuk makan lah ya pak gajinya?

O.. iya. Gak bisa untuk yang lain2 walaupun ada THR dan bonusan itu pun kalau hari raya.

$\mathrm{N} \quad$ : Makanya ada istri para karyawan yang ikut suaminya kerja. Ikut suaminya biar berharap dapat target kerja yang lebih. Kan lumayan menambah uang belanja.

Selain itu, para istri karyawan juga banyak yang ikut membantu para suami dalam bekerja. Hal ini dilakukan oleh para istri agar hasil panen atau hasil pekerjaan suami mereka melampaui target. Ada juga ibu-ibu yang bekerja secara pribadi di perkebunan bukan karena membantu suami tetapi memang secara pribadi mengerjakan pekerjaan ringan di kebun. Berikut cuplikan wawancara dengan informan.

W : Ibu-ibunya juga mengerjakan pekerjaan seperti bapak-bapaknya ya pak?

$\mathrm{N} \quad$ : Ya gak semua sih. Tapi ada juga ibu-ibu yang kerja tapi yang ringan-ringan la.. misalnya pembibitan, menanam kecambah kelapa sawit, dan nyiram-nyiram juga

W : Masih sampai saat ini pak?

$\mathrm{N} \quad$ : Sebenarnya jika darurat ibu-ibu bisa aja dipekerjakan untuk pemberantasan gulma-gulma ringan misalnya di jalur-jalur pohon karet.

W : Apakah kegiatan meracun ini juga bisa dilakukan oleh ibu-ibu itu pak?

$\mathrm{N}$ : Pada umumnya kerjaan meracun gulma ini dilakukan oleh laki-laki, memang ada juga ibu-ibu yang nyemprot juga tapi ya gak banyak itu yang bisa.

Kesejahteraan karyawan yang didukung oleh sistem SKU, pendapatan dari lembur, dan juga peran ibu-ibu di Perkebunan Fajar Agung ini menciptakan stigma bahwa bekerja di kebun ini memang cukup menjanjikan walaupun upahnya kecil. Faktor kesejahteraan dan jaminan kehidupan yang layaklah yang membuat secara tidak langsung kebertahanan bahasa Jawa pada masyarakat Jawa di Perkebunan Fajar Agung, khususnya pengetahuan leksikon kegulmaan tetap terjaga dengan baik karena mereka semua terlibat di dalam pekerjaan di perkebunan ini. Terkiat dengan kesejahteraan, hasil wawancara sesuai penelitian Kurniawan, Usman, \& Iswary, 2019, yang menyampaikan bahwa tingkat kesejahteraan bagi para pekerja di perkebunan selalu menjadi polemik tersendiri yang berkepanjangan. Hal terlihat pada kutipan wawancara berikut ini. 
W : Di menejemen yang baru ini pak, dari mana para pekerjanya?

$\mathrm{N}$ : Karyawan tetap diambil dari kebun ini sendiri. Ya anak-anaknya lah.

W : Kalo gak kuliah, biasanya anak-anaknya kerja gitu pak?

O.. iya, mereka bisanya kalo gak sekolah lagi ya biasanya gantïn bapaknya kerja di kebun. Jadi

$\mathrm{N}$. memang pekerjaan di kebun ini bisa jadi cita-cita anak-anak yang tidak lagi sekolah. Mereka ini maunya kayak orang tua mereka hidup di kebun ini. Karena di kebun ini kan semua dijamin oleh perusahaan. Jadi ya mereka senang kerja di kebun.

\section{Pendidikan Masyarakat Jawa Fajar Agung}

Pendidikan dapat dimaknai sebagai proses pengubahan sikap dan tata laku seseorang sebagai usaha pembentukan karakter manusia melalui usaha pengajaran dan pelatihan dalam wujud proses cara dan mendidik. Permasalahan pendidikan anak-anak di Perkebunan Fajar Agung memang cukup menjadi perhatian tersendiri. Sebab semuanya bermula dari kondisi orang tua mereka yang turun-temurun tinggal di sana dan bekerja sebagai karyawan.

Walaupun sarana dan prasarana pendidikan seperti SD Negeri, SMP Negeri, dan SMA Negeri sudah tersedia di perkebunan tersebut, nampaknya pemikiran untuk tetap bekerja sebagai karyawan di perkebunan tersebut masih ada. Hal ini disebabkan daya tarik sistem SKU perkebunan ini. Memang akhirakhir ini banyak juga anak-anak perkebunan yang melanjutkan sekolahnya ke jenjang perguruan tinggi, bahkan ada juga yang melanjutkan ke jenjang pascasarjana. Namun, itu semua bila orang tuanya mau anaknya berubah nasibnya. Semua memang kembali ke orang tua juga. Berikut cuplikan wawancara dengan informan.

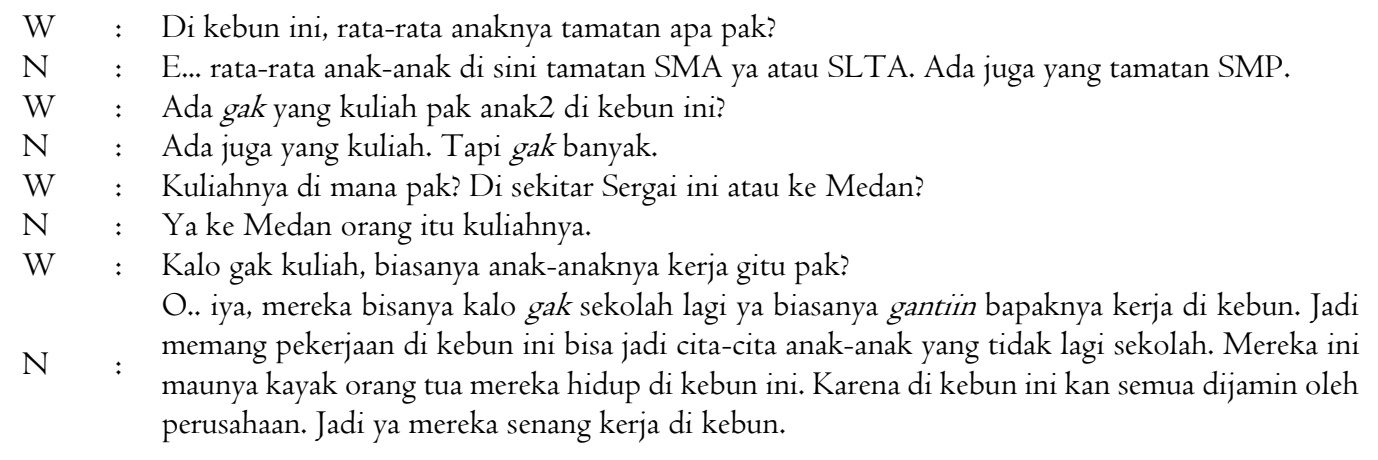

Apabila anak-anak di perkebunan ini tetap tinggal dan bekerja, maka kemungkinan besar kebertahanan pengetahuan anak-anak di kebun ini tentang leksikon kegulmaan masih tetap terjaga dengan baik. Hal ini dikarenakan pekerjaan mereka yang membuat mereka terpaksa tetap bersentuhan dan akrab dengan leksikon-leksikon tersebut. hal ini sejalan dengan penelitian Shin, Mangku, dan Collins (2018) yang menyatakan bahwa pemilihan bahasa menjadi salah satu hal yang tetap mempertahankan keberlangsungan leksikon kegulmaan di tengah-tengah masyarakat perkebunan.

\section{SIMPULAN}

Secara empiris dapat disimpulkan bahwa tingkat pemahaman MJFA terhadap leksikon kegulmaan menunjukkan bahwa pemahaman responden kedua kelompok usia, baik usia I maupun usia II pada kategori T (Tahu) terhadap gulma merupakan kategori yang sangat baik. Walaupun ada indikasi mulai adanya beberapa leksikon yang sudah dilupakan baik kelompok usia I maupun usia II. Selain itu, penelitian ini agak berbeda dari penelitian lainnya karena pengetahuan kelompok usia I (25-45 Tahun) lebih tinggi persentasenya $83,53 \%$. Jumlah ini lebih tinggi dibandingkan dengan kelompok usia II (46-60 Tahun) dengan jumlah 83, I5\%. Berkaitan dengan faktor kebertahanan leksikon kegulmaan, dapat disimpulkan terdapat dua jenis faktor, yaitu faktor yang berkaitan dengan linguistik dan non-linguistik. Faktor linguistik yang memengaruhi kebertahanan leksikon kegulmaan pada MJFA, yaitu berhubungan dengan tendensi MJFA terhadap bahasa Jawa. Kemudian faktor non-linguistik, yaitu perilaku konservatif MJFA 
terhadap gulma, adaptasi fisiologi gulma terhadap herbisida, konsistensi penggunaan peralatan tradisional pengendalian dan pemberantasan gulma, kesejahteraan MJFA, pendidikan MJFA.

Berdasarkan hasil penelitian tersebut, dapat ditarik suatu usaha inventarisasi dan pemertahanan bahasa lokal sebagai kekayaan bangsa Indonesia yang memerlukan perhatikan. Beberapa rekomendasiyang meliputi (I) keluarga sebagai faktor utama dalam pengajaran bahasa. Oleh sebab itu, orang tua perlu mengajarkan tentang bahasa daerah, khususnya bahasa Jawa kepada anak-anaknya sehingga mereka tidak kehilangan jati diri sebagai orang Jawa. (2) Untuk manajemen perusahaan agar arif dalam pengendalian dan pemberantasan gulma, misalnya menggunakan predator alami atau menggunakan racun alami yang dapat menjaga keseimbangan ekosistem di perkebunan. Hal ini akan berdampak baik pada pengetahuan masyarakat tentang jenis-jenis gulma yang dapat dimanfaatkan. (3) Masyarakat harus tetap mempertahankan penggunaan bahasa daerah dengan tidak meninggalkan bahasa Indonesia sebagai bahasa pemersatu bangsa.

\section{UCAPAN TERIMA KASIH}

Tim peneliti mengucapkan terima kasih kepada pihak-pihak Perkebunan Fajar Agung beserta jajarannya yang telah membantu kami melakukan eksplorasi dan memberikan ruang dan waktu yang begitu luas, sehingga mendapatkan informasi yang begitu berharga demi kemajuan ilmu dan teknologi. Kami juga mengucapkan kepada Ketua Prodi Program Lingusitik, Universitas Sumatera Utara dan juga beserta jajarannya yang telah memberikan masukan dan juga gagasan penting demi kemajuan penelitian ini. Akhirnya kami juga sampaikan terima kasih kepada semua pihak yang telah memberikan berbagai kontribusinya dalam pelaksanaan penelitian ini

\section{DAFTAR PUSTAKA}

Adjeng, A. N. T., Ruslin, R., \& Pascayantri, A. (2020). Sosialisasi dan edukasi pemanfaatan tanaman berkhasiat obat dalam menghadapi masa pandemi covid-I9 di Kota Kendari. Jurnal Mandala Pengabdian Masyarakat, I(2), 62-69. https://doi.org/I0.353II/jmpm.vIi2.I3

Adliza, A., Oktavianus, O., \& Usman, F. (202I). Leksikon verba dan nomina bahasa Tanjung Pucuk Jambi Kabupaten Tebo Provinsi Jambi dalam lingkungan perladangan: Kajian ekolinguistik. LINGUA: Jurnal Bahasa, Sastra, dan Pengajarannya, I8(I), 48-6I. https://doi.org/I0.30957/lingua.vI8iI.67I

Adriyani, R. (2006). Usaha pengendalian pencemaran lingkungan akibat penggunaan pestisida pertanian. Jurnal Kesehatan Lingkungan, 3(I), 95-I06. Retrived from https://dIwqtxtsIxzle7.cloudfront.net/573I43I5/Control_of_Environmental_Pollution_ca use-with-cover-page-

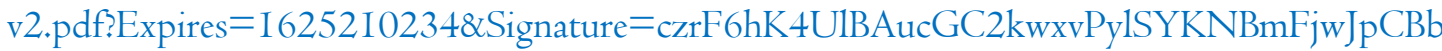
Y0k2eAjPCb9PTjYfldhVBfSIrIBdiUg-0 cGovGeFIDxXeNTqFAHB0cftsp3qnzc8vxwiA9yH4cKF3iR5RqquTIoFaCizM-

LyNpH4LdIGXqGdDKGNq73I08pAMUY4IOvbVAVX6aID4wn7Lx0yLxGCkdO0SVqn 9zn7RDAJDEA2efD1OpkFcl4BdGfMVWkWIOc2zWmv6pQ7wImgfviqidqqxc16XGvEuPJ

LtEz-VUHznCP8b7Ko546f6Q9LAK0ZzbbeIRb2xiT d8nMbqzVwIxgCn6pyM6z8B8Es7JtJh-tEOA4A_\&Key-Pair-Id=APKAJLOHF5GGSLRBV4ZA

Amano, T., Sandel, B., Eager, H., Bulteau, E., Svenning, J. C., Dalsgaard, B., \& Sutherland, W. J. (20I4). Global distribution and drivers of language extinction risk. Proceedings of the Royal Society B: Biological Sciences, 28I(I793), I587-I574. https://doi.org/I0.1098/rspb.2014.1574

Arif, A. (2015). Pengaruh bahan kimia terhadap penggunaan pestisida lingkungan. Jurnal Farmasi UIN Alauddin Makassar, 3(4), I34-I43. https://doi.org/I0.24252/jurfar.v3i4.22I8

Fasold, R. (200I). The Sociolinguistics of Society. USA: Blackwell. 
Fill, Anwar. (200I). The Ecolinguistics Reader Language, Ecology And Environment. London: Continum.

Fishman, J. A. (1972). The Sociology of Language. Rowley, Massachusetts: Newbury House Publishers.

Fitria, A., Rabiâ, A., \& Syahrani, A. (2019). Pemertahanan leksikon kemaritiman dalam bahasa Melayu Sambas di Desa Jawai Laut. Jurnal Pendidikan dan Pembelajaran Khatulistiwa, 8(3), I-8. Retrived from https://jurnal.untan.ac.id/index.php/jpdpb/article/view/31906/75676580493

Genua, V. (2018). Makna teks kenangibho bewa 'ratapan'dalam ritual matamosalaki tradisi etnik Lio Ende Flores: Perspektif ekolinguistik. Tutur: Cakrawala Kajian Bahasa-Bahasa Nusantara, 4(2), I33-I4I. Retrived from http:/ / tutur.apbl.org/index.php/tutur/article/view/84

Ghazali, N., Jaafar, M. F., \& Radzi, H. (2019). Peralihan bahasa Cham dalam Masyarakat Cham di Malaysia: Analisis Sosiolinguistik (Language Shift among the Malaysian Cham Community: A Sociolinguistic Analysis). GEMA Onlineß Journal of Language Studies, I9(2), 52-69. http://dx.doi.org/10.17576/gema-2019-1902-04

Herdiansyah, E. (2017). Kehidupan kuli kontrak Jawa di perkebunan tembakau Sumatera Timur tahun 1929-1942. Avatara 5(3), 13-24. Retrived from https://jurnalmahasiswa.unesa.ac.id/index.php/avatara/article/view/2I033

Hidayah, N., Dharmawan, A. H., \& Barus, B. (2016). Ekspansi perkebunan kelapa sawit dan perubahan sosial ekologi pedesaan. Sodality: Jutnal Sosiologi Pedesaan, 4(3), 249-56. Retrived from I4434-Article\%20Text-42577-I-I0-20161225.pdf

Iku, P. F. (2020). Faktor-faktor pemertahanan khazanah lingual kepadian pada masyarakat tutur bahasa Manggarai. PROLITERA: Jumal penelitian pendidikan, bahasa, sastra, dan budaya, 3(I), I07II I. https:// doi.org/I0.36928/jpro.v3iI.629

Iyung, Pahan. (2008). Panduan lengkap kelapa sawit manajemen agribisnis dari hulu hingga hilir. Jakarta: Penebar Swadaya.

Jupitasari, M. (202I). Leksikon etnomedisin pada pengobatan penyakit kulit melayu sukadana: Kajian ekolinguistik. Jurnal Elektronik Wacana Etnik, IO(I), I-9. http://dx.doi.org/I0.25077/we.vI0.iI.I56

Kadek, N., Dwiyani, S. S., \& I Kadek, P. (20I4). Peran stasiun televisi lokal di Bali dalam upaya pemertahanan bahasa Bali sebagai bahasa ibu. Segara Widya, I(I), 23-36. retrived from http://repo.isi-dps.ac.id/2362/

Kardi, G., Madeten, S. S., \& Syahrani, A. (2019). Leksikon perpadian dalam masyarakat Dayak Jalai di Kabupaten Ketapang. Jurnal Pendidikan dan Pembelajaran Khatulistiwa, 8(9), I-I2. Retrived from https://jurnal.untan.ac.id/index.php/jpdpb/article/view/3544I

Keman, S. (200I). Bahan ajar toksikologi lingkungan. Surabaya: Fakultas Kesehatan Masyarakat Universitas Airlangga.

Kurniawan, M. A., Usman, M., \& Iswary, E. (2019). Kearifan ekologis dalam leksikon bahasa rimba di hutan bukit duabelas Jambi: Kajian ekolinguistik. Jurnal Ilmu Budaya, 7(I), 30-42. Retrived from https://journal.unhas.ac.id/index.php/jib/article/view/6368

Mahayana, I. M. A., Sukiani, N. K., Suwendri, N. M., \& Winaya, M. D. (2019). Leksikon-leksikon flora dalam metafora bahasa Bali: Kajian Ekolinguistik. KULTURISTIK: Jurnal Bahasa dan Budaya, 3(2), 4I-50. https://doi.org/I0.22225/kulturistik.3.2.II92

Mahsun. (1995). Dialektologi diakronis suatu pengantar. Yogyakarta: Gadjah Mada University Pers.

Mardikantoro, H. B. (2016). Pemertahanan bahasa Jawa dalam pertunjukan kesenian tradisonal di Jawa Tengah. LITERA, I5(2), 269-280. https://doi.org/I0.2I83I/ltr.vI5i2.II828

Mbete, Aron Meko. (2009). Ekolinguistik: Perspektif kelinguistikan yang prospektif. Denpasar: Universitas Udayana. 
Mufwene, S. S. (2002). Colonization, globalization and the plight of 'weak'languages. Journal of linguistics, 38(2), 375-395. https://doi.org/I0.1017/S002222670200139I

Ndruru, M. (2020). Leksikon Flora pada bolanafo bagi guyub tutur Nias kajian ekolinguistik. Jurnal Education and Development, 8(2), 257-257. Retrived from http://journal.ipts.ac.id/index.php/ED/article/view/I69I

Nurdin, N. B. (2012). Pergeseran dan pemertahanan bahasa. Diglossia: Jurnal Kajian Ilmiah Kebahasaan dan Kesusastraan, 4(I), I-7. http://dx.doi.org/I0.26594/diglossia.v4iI.226

Rafael, A. M. D., \& Ate, C. P. (2020). Pemertahanan bahasa Tetun dalam guyub tutur masyarakat bekas pengungsi Timor-Timur di Desa Manusak Kabupaten Kupang. KEMBARA: Jurnal Keilmuan
Bahasa,
Sastra,
dan Pengajarannya
(e-Journal),
6(I),
27-38.

https://doi.org/I0.22219/kembara.v6iI.II708

Rajistha, I. G. N. A. (2016). Beblaba dan bahasa Bali dalam perspektif ekolinguistik. RETORIKA: Jurnal Ilmu Bahasa, 2(I), 79-94. https://doi.org/I0.22225/jr.2.I.50.79-94

Santoso, W. J. (2017). Analisis sosio-ekono-ekolinguistik terhadap pemertahanan leksikon tanaman tradisonal untuk bumbu masak bagi mahasiswi di Kota Semarang. JP-BSI (Jurnal Pendidikan Bahasa dan Sastra Indonesia), 2(2), 69-76. https://dx.doi.org/I0.26737/jp-bsi.v2i2.250

Sari, M. Y., Rabiâ, A., \& Syahrani, A. (2019). Khazanah leksikon kelautan dalam bahasa melayu dialek sukadana. Jumal Pendidikan dan Pembelajaran Khatulistiwa, 8(3), I-I0. Retrived from https://jurnal.untan.ac.id/index.php/jpdpb/article/view/31630

Shin, Chong, Hendrikus Mangku, and James Thomas Collins. (2018). Pemilihan Bahasa Komuniti Penan Muslim di Sarawak (The Language Choices of the Muslim Penan Community in Sarawak). GEMA Online $\mathbb{R}$ Journal of Language Studies, I8(4), 6I-80. 10.17576/gema-2018-1804-05.

Sinungharjo, F. X. (2020). Leksikon biotik di panggung musik: Perspektif ekolinguistik. Sintesis, I4(2), I09-I30. https:// doi.org/I0.2407I/sin.vI4i2.2675

Spolsky, Bernard. (2009). Language Management. Cambridge: Cambridge University Press.

Sugiono. (2015). Metode penelitian kuantitatif, kualitatif, dan R\&D. Bandung: Alfabeta.

Sujana. (2010). Metoda statistika. Jakarta: Tarsito.

Suktiningsih, W. (2016). Dimensi Praksis dan model dialog leksikon fauna masyarakat Sunda: Kajian ekolinguistik. Retorika: Jurnal Ilmu Bahasa, 2(I), I42-I60. https://doi.org/I0.22225/jr.2.I.54.I42-I60

Syamsuddin, Vismaia. (2015). Metode penelitian pendidikan bahasa. Bandung: Rosda Karya.

Tampubolon, Koko, dan Purba, Edison. (2018). Konfirmasi resistensi eleusine indica terhadap glifosat pada perkebunan kelapa sawit di Kabupaten Langkat. Jurnal Pertanian Tropik, 5(2), 276-83. https://doi.org/10.32734/jpt.v5i2.3016

Tarigan, B., \& Sofyan, R. (2017). Local wisdom in the ecolexicon used in the new version of Karonese traditional game "cengkah-cengkah". In 6th International Conference on Language and Arts (ICLA), Padang, West Sumatra, Indonesia (pp. I8-I9).

Thatsanai, R. (2017). The Promoting factor for co-existence with thais: A case study of migrant workers in Pathum Thani, Thailand. Asian Political Science Review, I(2). Retrived from https://papers.ssrn.com/sol3/papers.cfm?abstract_id=3180707

Thomason, Sarah Grey. (20I I). Language Contact: An introductiomn. Edinburgh: Edinburgh University Press.

Wharton, Amy S. (2005). The sociology of gender: An introduction to theory and research. Malden, MA: Blackwell Pub.

Widyanigrum, H. K. (2017). Campur Kode Siaran Radio Most FM Penyiar Ari di Kota Malang. KEMBARA: Jurnal Keilmuan Bahasa, Sastra, dan Pengajarannya (e-Journal), 3(I), 4954. https://doi.org/I0.22219/kembara.v3iI.4377 
Wirianta, G., \& Umiyati, M. (2016). Matriks fungsi morfem sesenggakan bahasa Bali: Kajian ekolinguistik. RETORIKA: Jumal Ilmu Bahasa, 2(2), 409426. https://doi.org/I0.22225/jr.2.2.69.409-426 